\title{
Karakteristik Arus di Perairan Pulau Weh Pada Musim Peralihan 1 dan Kaitannya dengan Fluktuasi Suhu Permukaan Laut
}

\author{
Ulung J. Wisha ${ }^{1} *$ dan Elma T. Situmeang ${ }^{2}$ \\ ${ }^{1}$ Loka Riset Sumber Daya dan Kerentanan Pesisir, Kementerian Kelautan dan Perikanan \\ Jl. Raya Padang Painan Km. 16, Bungus, Padang Sumatra Barat 25245 \\ ${ }^{2}$ Departemen Ilmu Kelautan, Fakultas Matematika dan Ilmu Pengetahuan Alam, Universitas Sriwijaya \\ Jl. Palembang - Prabumulih KM.32 Kabupaten Ogan Ilir, Sumatera Selatan 30862 \\ Email: ulungjantama@gmail.com
}

\begin{abstract}
Abstrak
Posisi Pulau Weh yang strategis membuat kawasan ini unik dalam hal karakteristik oseanografi fisik. Transfer massa air di Pulau Weh sangat signifikan yang akan berdampak pada sebaran suhu perairan di sekitar kawasan pesisir. Tujuan dari penelitian ini adalah untuk mengetahui perubahan perpindahan massa air secara vertikal dan hubungannya terhadap perubahan suhu perairan. Tiga area penting diobservasi yang mewakili utara, timur, dan selatan pulau weh yakni kawasan Iboih, Ie Meulee, dan Keunekai. Tiga ADCP diinstal pada ketiga titik observasi tersebut. Secara vertikal, komponen kecepatan arus zonal dan meridional menunjukkan kecepatan yang lebih acak saat menuju ke permukaan dengan kecepatan kurang dari 0,5 $\mathrm{m} /$ detik. Identifikasi pasang surut elips pada seluruh stasiun membuktikan bahwa di perairan Pulau Weh, arus pasang surut dangat dominan yang mana faktor lain juga memiliki pengaruh dalam memicu perpindahan massa air di permukaan. Arah arus dominan berputar sesuai dengan kaidah Spiral Ekman dan pengaruh gaya Coriolis. Fluktuasi suhu mengikuti perubahan elevasi pemukaan dan kecepatan arus yang berkisar antara 25$35^{\circ} \mathrm{C}$. Pada penelitian ini, menunjukkan bahwa pada bagian utara (Iboih) dan selatan (Keunekai) Pulau Weh, fluktuasi suhu berlangsung secara berlawanan menyerupai "jungkat-jungkit" yang mengindikasikan peran besar dari transfer massa air dari Laut Andaman dan Samudera Hindia yang membawa massa air hangat selama musim perlaihan I.
\end{abstract}

Kata kunci : Perpindahan massa air, suhu permukaan, Pulau Weh

\begin{abstract}
Sea Current Characteristics in Weh Island During the first Transitional Monsoon and Its Relation to Sea Surface Temperature Fluctuations
\end{abstract}

The strategic position of Weh Island makes this region is unique in terms of physical oceanography characteristics. Water mass transport in Weh Island is tremendously significant, whereby it will affect the distribution of temperature in the surrounding coastal area. This study aimed to determine the changes in vertical water mass movement and its relation to water temperature alteration. We observed three vital areas representing north, east, and south parts of Weh Island waters, namely Iboih, Ie Meulee, and Keunekai, respectively. Three ADCPs were installed at those three observation points. Vertically, the zonal and meridional current components showed a more randomly speed surface-ward with less than $0.5 \mathrm{~m} / \mathrm{s}$ magnitude. Tidal ellipses identification at all stations proved that in the Weh Island, tidal current is predominant. Other factors also trigger water mass movement on the surface. Sea current dominant direction rotated as the Ekman Spiral and Coriolis force influence. Temperature fluctuation followed the surface elevation and current speed changes ranging from $25-35^{\circ} \mathrm{C}$. In this study, it shows that between northern (Iboih) and southern (Keunekai) part of Weh Island, the temperature fluctuation oppositely takes place like a "see saw" indicating the significant role of water mass transfer from the Andaman Sea and the Indian Ocean which brings warm water during the first transitional season.

Keywords: Water mass movement, surface temperature, Weh Island 


\section{PENDAHULUAN}

Pengetahuan mengenai profil massa air pada suatu perairan sangat diperlukan untuk menggambarkan karakteristik suatu perairan yang mana dapat menggambarkan mekanisme transport dan kesuburan perairan. Menurut Aryono et al. (2014), tingkat kesuburan suatu perairan berkaitan dengan transport vertikal di dalam kolom air. Proses pencampuran ini memiliki peran penting untuk mendukung kelangsungan hidup biota perairan. Pengamatan pada perpindahan masa air dapat dilakukan dengan melihat profil kecepatan arus di tiap lapisan perairan dan dipermukaan, serta mengamati sebaran suhu permukaan laut sebagai dampak mekanisme transfer massa air.

Pulau Weh merupakan salah satu pulau terluar yang menjadi wilayah yang sangat penting di Indonesia sebagai pusat kawasan maritim, dipengaruhi oleh kondisi dipole mode berbatasan dengan Samudera Hindia di sebelah Barat dan Selat Malaka di sebelah Timur serta Laut Andaman di sebelah Utara (Wisha et al., 2019a). Secara geografis, pulau tersebut terletak di Laut Andaman yang termasuk busur vulkanik Sunda dan terhubung dengan perairan Selat Malaka di bagian timur. Produktifitas perairan di sekitar Pulau Weh tergolong tinggi dengan aktifitas perikanan yang juga sangat bagus (Natsir dan Wibowo, 2019).

Karena letak geografis Pulau Weh yang sangat srategis, maka pola perpindahan masa air yang terjadi sangat dipengaruhi oleh interaksi antara laut dan atmosfer dimana faktor iklim memiliki peran besar terhadap kondisi oseanografi di Pulau Weh. Parameter yang paling mudah untuk diamati adalah arus laut dan suhu permukaan (Napitu et al., 2016), sehingga untuk mengambarkan pola transfer massa air dapat didekati melalui karakteristik arus laut dan dampaknya dapat diperlihatkan dengan pemantauan suhu periaran baik di permukaan maupun di kolom perairan. Di sisi lain, suhu perairan di Pulau Weh juga dipengaruhi oleh fenomena Indian Ocean Dipole (IOD) yang aktif dalam mengendalikan naik dan turunnya suhu antara barat Sumatra dan timur Afrika. Dalam pemabgian pola iklim Indonesia, Pulau Weh berada pada kawasan seminonsun dimana pola curah hujan maksimum terjadi dua kali (dua puncak curah hujan), selain berpengaruh besar terhadap curah hujan, aktifitas monsoon juga memicu pergerakan angin permukaan yang akhirnya mempengaruhi pola dan karakteristik arus di Perairan (upwelling dan downwelling) (Silubun et al., 2016).
Salah satu upaya pengamatan karakteristik arus laut dan hubungannya dengan perubahan suhu perairan di Pulau Weh sangat perlu dilakukan karena signifikansi kawasan Pulau Weh sebagai area wisata dan area konservasi maritim karena kedua faktor fisis terbeut memiliki peran besar dalam penentuan kondisi perairan, mendukung kelestarian sumberdaya baik hayati maupun non hayati. Selain itu, kondisi arus dan suhu perairan juga menjadi faktor penentu area upwelling untuk kepentingan penentuan daerah tangkapan ikan. Sehingga identifikasi pola arus, perpindahan massa air lokal, dan kondisi suhu perairan sangat penting untuk dilakukan. Pengamatan ini bertujuan untuk mengetahui perubahan massa air secara vertikal dan hubungannya terhadap perubahan suhu perairan.

\section{METODE PENELITIAN}

Penelitian dilakukan di 3 lokasi pengamatan di Pulau Weh (Gambar 1) yaitu Iboih terletak di 95'13'15,6” BT dan 5'54'21,6” LU, Keunekai terletak di $95^{\circ} 18^{\prime} 43,2^{\prime \prime}$ BT dan $5^{\circ} 46^{\prime} 30^{\prime \prime}$ LU dan Ie Meulee terletak di $95^{\circ} 20^{\prime} 20,4^{\prime \prime}$ BT dan 5'53'38,4" LU. Penentuan lokasi bertujuan untuk mewakili seluruh perairan Pulau Weh. Data primer yang digunakan merupakan data per jam kecepatan arus dan suhu in situ hasil perekaman ADCP (Acoustic Doppler Current Profiler) selama 20 hari pengukuran (16 Maret hingga 5 April 2017) yang mewakili musim peralihan I.

Data hasil perekaman ADCP akan diolah menjadi profil vertikal komponen arus menggunakan komponen arus (east, north dan up), scatter plot dan grafik arus in situ menggunakan Microsoft Excel, menjadi current rose menggunakan Grapher 8 dan menjadi profil kecepatan arus dengan data sekunder arus pasang surut yang diperoleh melalui NAOTide. Sedangkan untuk data suhu in situ disortir dan dianalisis secara statistik.

\section{HASIL DAN PEMBAHASAN}

\section{Profil Vertikal Komponen Kecepatan Arus}

Profil vertikal arus menunjukkan
pergerakan
komponen kedalaman. Setaip garis pada Gambar 2 menunjukkan nilai dari kecepatan komponen arus, setiap warna merwakili satu jam pengamatan dimana terdapat perbedaan kecepatan komponen arusnya. Dalam diagram cartesius (x, y, z), komponen east velocity menunjukkan pergerakan komponen arus yang bergerak pada sumbu horizontal (x), sedangkan komponen north 
velocity menunjukkan pergerakan komponen arus yang bergerak pada sumbu vertikal (y) dan komponen up velocity menunjukkan pergerakan komponen arus yang bergerak ke permukaan (z). Arus merupakan besaran vektor karena memiliki kecepatan dan arah yang tersusun atas 3 komponen tersebut.

Komponen up velocity di Perairan Iboih memiliki kecepatan rata-rata $0,01 \mathrm{~m} / \mathrm{s}$ di sepanjang kolom perairan dimana tidak terjadi perubahan kecepatan komponen arus disetiap perubahan kedalaman. Komponen north velocity memiliki kecepatan rata-rata di permukaan 0,23 $\mathrm{m} / \mathrm{s}$ dan $0,12 \mathrm{~m} / \mathrm{s}$ pada kedalaman $10 \mathrm{~m}$. Untuk komponen east velocity kecepatan berkisar antara $0-0.3 \mathrm{~m} / \mathrm{s}$. Komponen arus zonal dan meridional mengalami peningkatan kecepatan saat mendekati permukaan dimana pengauh tranfer energi angin memiliki peran besar dalam peningkatan kecepatan arus permukaan (Wisha et al., 2018). Sedangkan didekat dasar banyak gaya penghambat gerak arus seperti peningkatan densitas, gaya gesakan dasar dan faktor fisis lainnya. Namun, kondisi tersebut akan bergantung pada bentukan morfologi dasar pada suatu perairan.

Komponen east velocity pada perairan Ie Meulee memiliki kecepatan rata-rata $0,01 \mathrm{~m} / \mathrm{s}$ dipermukaan dan $0,005 \mathrm{~m} / \mathrm{s}$ di kedalaman $10 \mathrm{~m}$. Komponen up velocity memiliki rata-rata $0,01 \mathrm{~m} / \mathrm{s}$ di permukaan dan di kedalaman $10 \mathrm{~m}$. Sedangkan komponen north velocity terlihat sedikit lebih acak dan memiliki kecepatan rata-rata $0,19 \mathrm{~m} / \mathrm{s}$ di permukaan dan 0,16 di kedalaman $10 \mathrm{~m}$, hal ini menunjukkan perubahan yang tidak terlalu signifikan hampir disemua jam pengamatan akan tetapi pada periode tertentu, terdapat perubahan pengaruh komponen meridional seiring dengan bertambahnya kedalaman. Kondisi tersebut dapat disebabkan oleh proses asimetri antara energi yang ditransfer oleh angin dengan densitas pada kolom perairan sehingga perpindahan massa air secara vertikal cenderung tidak menentu. Kemungkinan adanya pengaruh arus internal (arus non pasut) menyebabkan fluktuasi komponen kecepatan arus di Perairan Ie Meulee.

Pada Perairan Keunekai, komponen arus north dan up velocity menunjukkan perubahan yang relatif konstan. Komponen north velocity memiliki kecepatan rata-rata $0,11 \mathrm{~m} / \mathrm{s}$ di permukaan dan $0,1 \mathrm{~m} / \mathrm{s}$ di kedalaman $10 \mathrm{~m}$. Komponen up velocity memiliki kecepatan ratarata $0,01 \mathrm{~m} / \mathrm{s}$ di permukaan dan 0,02 di kedalaman $10 \mathrm{~m}$. Sedangkan komponen east velocity dengan kecepatan maksimal $0,5 \mathrm{~m} / \mathrm{s}$ dan kecepatan ratarata $0,18 \mathrm{~m} / \mathrm{s}$ dipermukaan dan $0,12 \mathrm{~m} / \mathrm{s}$ di kedalaman $10 \mathrm{~m}$, menunjukkan adanya pengaruh yang besar pada lapisan permukaan dan semakin bertambahnya kedalaman maka pengaruh komponen arus ini akan semakin berkurang karena mengalami gesekan dengan densitas perairan yang semakin besar pada lapisan kedalaman.

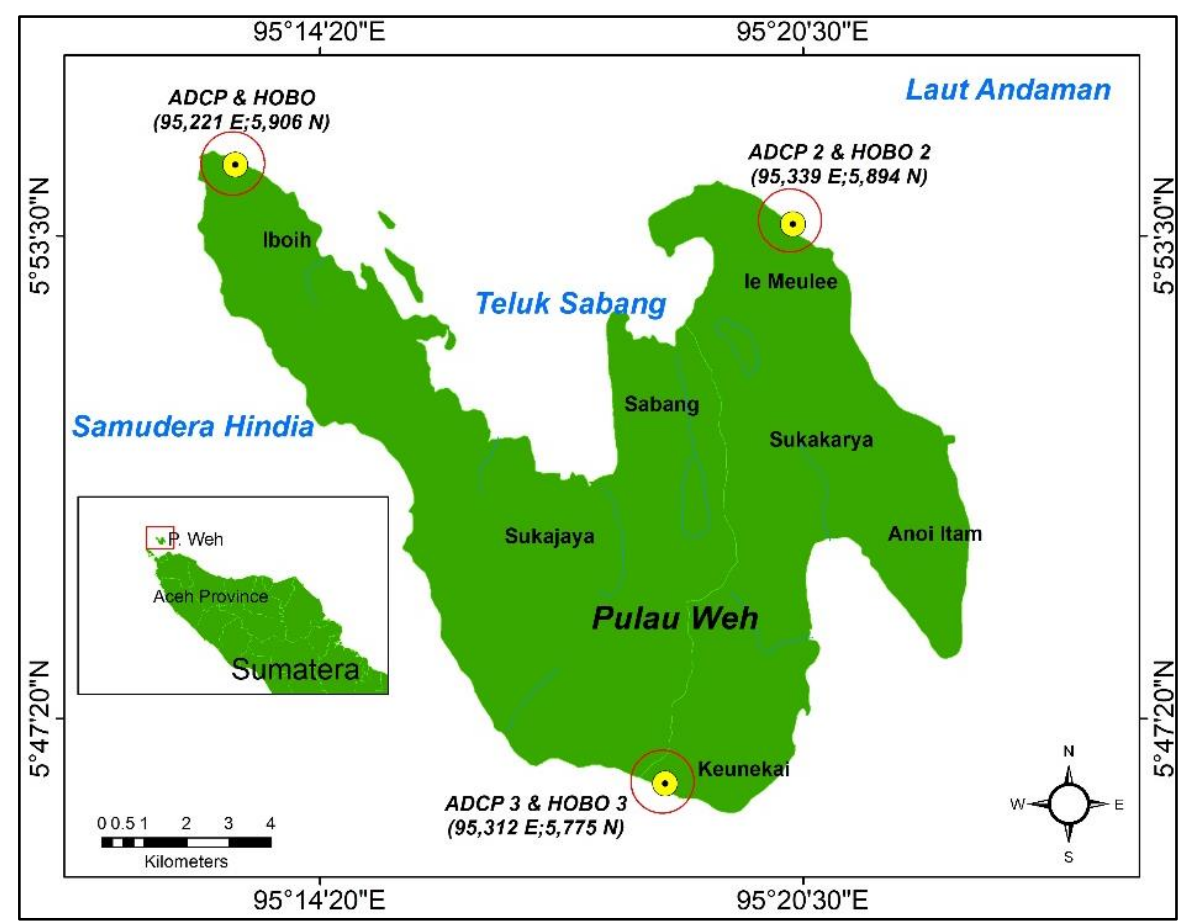

Gambar 1. Peta Lokasi Pengamatan 


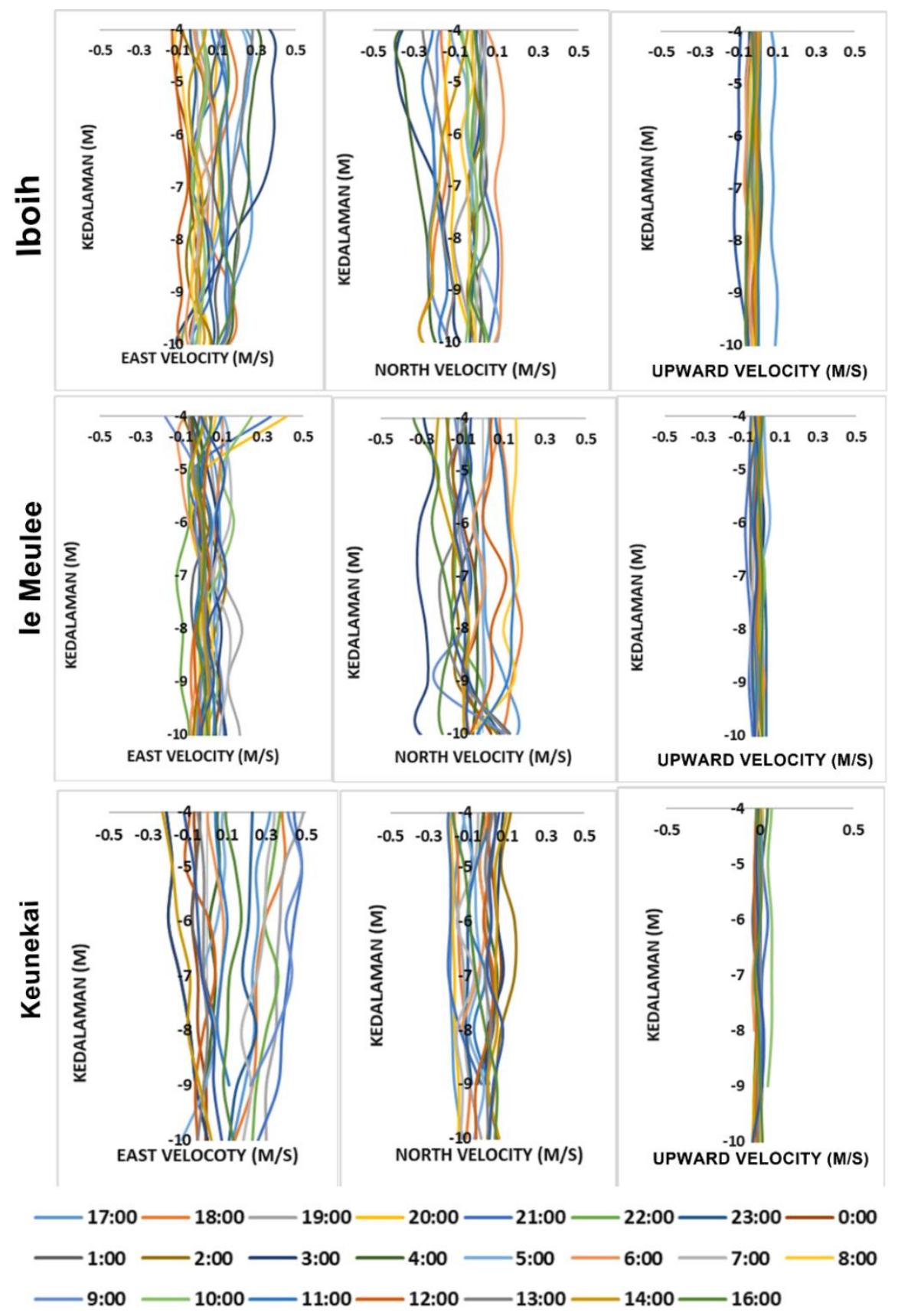

Gambar 2. Profil Vertikal Komponen Arus

Secara umum, nilai komponen kcepatan arus di Pulau Weh dominan positif yang mengindikasikan bahwa arus bergerak dari lapisan dalam membawa partikel terlarut atau massa air ke permukaan atau dikenal dengan proses upwelling pada perairan ini (Wisha dan Ilham, 2019). Komponen kecepatan arus pada ketiga titik pengamatan menunjukkan bahwa ada beberapa komponen yang mengalami mengalami perubahan yang relatif konstan dan juga komponen yang mengalami perbuhan secara bertahap. Hal ini disebabkan oleh perbedaan dari ketiga letak lokasi pengamatan yang berpengaruh pada komponen kecepatan arus perairan Pulau Weh. Jika dibandingkan dari ketiga lokasi pengamatan, perpindahan massa air lebih besar terjadi pada perairan Iboih dan Keunekai dimana berbatasan dengan Samudera Hindia. Samudera Hindia memiliki peran besar dalam mekanisme perpindahan mssa air dan transpor di perairan Pulau Weh (Gemilang and Wisha, 2019).

Kondisi arus di Perairan Iboih (Gambar 3) pada kedalaman 4 hingga 10 meter dari permukaan lebih fluktuatif disebabkan karena adanya pengaruh dari angin dan juga pasang surut. Hal tersebut menunjukkan bahwa pengaruh angin 
masih sangat besar di permukaan, sehingga arus yang ditimbulkan bersifat lebih acak. Semakin ke dalam dekat dasar, kecepatan arus mulai berkurang dan tidak menyebar, hal tersebut menandakan bahwa pengaruh gaya penghambat dan densitas perairan yang semakin besar. Selain itu, dapat dilihat juga bahwa pola dari dari scatter plot cenderung berbentuk elips dari Tenggara hingga Barat Laut. Hal ini mengindikasikan adanya pengaruh arus pasang surut yang dominan. Menurut Saputra et al. (2017), bentuk elips pada scatter plot tersebut menandakan arah pola arus pasang surut yang selalu bolak balik. Perairan Iboih berada di daerah Teluk Sabang atau perairan semi tertutup sehingga perairan tersebut mendapat pengaruh besar dari pasanga surut (Al Tanto et al., 2016).

Kondisi arus perairan Ie Meulee (Gambar 3) pada lapisan 4-6 meter menunjukkan menunjukkan keadaan arus yang menyebar akibat pengaruh angin dan pasan surut. Apabila dilihat pada lapisan dibawahnya 8 meter, kecepatan arus cenderung konstan, sedangkan pada lapisan bawah pada kedalaman 10 meter, kecepatan arusnya mulai menurun karena dalam proses perambatannya energi terkikis oleh gesekan anatara arus dengan massa air, sehingga kecepatan arus yang ditimbulkan oleh angin dan pasang surut semakin menuju ke dasar perairan akan semakin lemah (Wardheni et al., 2014).
Profil scatter plot arus di Perairan Keunekai pada lapisan mendekati permukaan dengan kedalaman 4 hingga 6 meter terlihat lebih fluktuatif dan menyebar, sedangkan pada kedalaman 8 hingga 10 meter dari permukaan, kecepatan menurun cukup signifikan, hal ini jelas, karena kondisi morfologi dasar peariran yang dipenuhi oleh tumpukan karang mati (Wisha et al., 2019b), menyebabkan profil arus yang lemah di dekat dasar karena terdapat hambatan fisik. Di sisi lain, Perairan Keunekai ini berada di selatan Pulau Weh yang berbatasan langsung dengan Samudera Hindia dan Laut Andaman sehingga berpengaruh langsung dengan kondisi perairan terutama perpindahan massa air di permukaan (Ondara et al., 2017).

\section{Dominasi Pergerakan Arus}

Pergerakan arus pada setiap kedalaman menunjukkan arah dan kecepatan yang berbeda. Pada lapisan permukaan kedalaman 1 meter di perairan Iboh (Gambar 4), pergerakan arus dominan kearah timur dan barat dengan kecepatan rata-rata $0,206 \mathrm{~m} / \mathrm{s}$. Pada kedalaman 5 meter arah arus didominasi ke arah barat-barat laut dengan kecepatan rata-rata $0,132 \mathrm{~m} / \mathrm{s}$. Pada kedalaman kedalaman 11 meter, arus bergerak secara dominan ke arah barat-barat laut (ke arah laut) dan

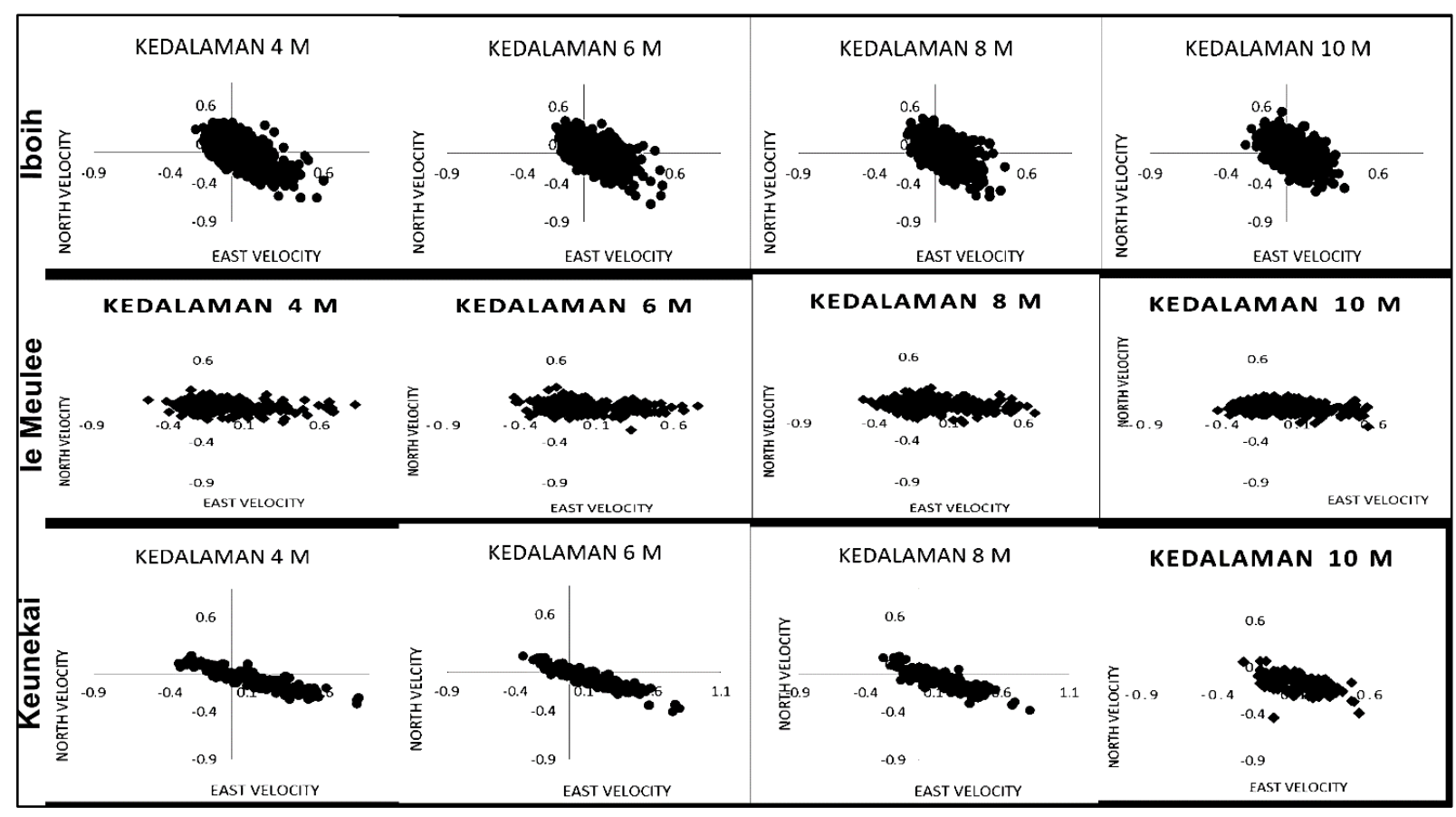

Gambar 3. Scatter plot komponen arus 
timur-timur laut (ke arah teluk) dengan kecepatan rata-rata $0,116 \mathrm{~m} / \mathrm{s}$. Perairan Iboih berada pada mulut Teluk Sabang sehingga perairannya bersifat semi tertutup dan pasang surut merupakan penggerak utama pada pergerakan massa airnya (Al Tanto et al., 2016) dan diasumsikan secara umum arus bergerak dari Laut Andaman menuju ke dalam teluk.

Pada di perairan Kenunekai, massa air bergerak di pemukaan hingga condong bergerak ke arah timur-tenggara (kearah Selat Malaka) dengan kecepatan rata-rata $0,383 \mathrm{~m} / \mathrm{s}$. Pada kedalaman 10 meter arah dominan arus bergeser ke arah tenggara-selatan dengan kecepatan ratarata $0,46 \mathrm{~m} / \mathrm{s}$. Pergeserah arah dominan arus ini menunjukkan adanya fenomena spiral Ekman (Wisha et al., 2019). Perairan Kenunekai berada di Selatan Pulau Weh dan perairan ini berbatasan langsung dengan Samudera Hindia dan Selat Malaka (Ondara et al., 2017) yang membuat pengaruh aktivitas samudra menjadi lebih besar terhadap perpindahan massa air di Pulau Weh dibandingkan dengan pengaruh dari pasang surut.

Berdasarkan pengukuran di Ie Meulee, arus permukaan bergerak ke arah tenggara-selatan dengan kecepatan rata-rata $0,413 \mathrm{~m} / \mathrm{s}$, sedangkan pada kedalaman 5 hingga 11 meter dominasi arah arus bergerak ke barat-barat Laut dan tenggara dengan kecepatan rata-rata $0,2 \mathrm{~m} / \mathrm{s}$. Perairan Ie Meulee berbatasan dengan Laut Andaman dan Selat Malaka sehingga membuat pengaruh interaksi antara laut dan atmosfer terhadap perpindahan massa air menjadi cukup tinggi. Menurut Wisha dan Ilham (2019), perairan Ie Meulee merupakan kawasan paling subur dengan tingkat biodiversitas yang cukup tinggi serta terdapat indikasi proses upwelling. Kejadian upwelling merupakan merupakan salah satu proses perpindahan massa air dari dasar menuu permukaan dan membawa zat hara ke permukaan, sehingga jelas bahwa perairan ini cukup signifikan dalam proses peningkatan kesuburan perairan akibat dari interaksi laut-atmosfer.

Kecepatan arus pada lapisan permukaan lebih tinggi yang dipengaruhi oleh angin dan pasang surut (Nuriyati et al., 2019). Semakin menuju ke dasar suatu perairan, maka kecepatan arus semakin melemah akibat semakin tinggi densitas perairan dan pergeseran arah gerak arus (Spiral Ekman). Hasil pengamatan dari tiga lokasi pengamatan (Gambar 4) juga menunjukkan bahwa semakin mengarah ke dasar perairan maka arus bergerak searah jarum jam. Dapat diasumsikan bahwa arus yang cepat memiliki massa air yang lebih ringan sehingga perubahan arah arusnya tidak signifikan, namun semakin kedalam perairan maka massa air semakin berat dan kecepatan arus melemah sehingga perubahan arah arusnya semakin besar. Hal ini disebabkan oleh pengaruh gaya gravitasi bumi dan gaya Coriolis yang menyebabkan arus pada Belahan Bumi Utara (BBU) berbelok kearah kanan dan menimbulkan spiral Ekman (Azis, 2006).

\section{Hubungan Kecepatan Arus dengan Pasang Surut}

Pada perairan Keunekai (Gambar 5) pasang tertinggi terjadi pada jam 05.00 dan 17.00 dengan ketinggian permukaan laut $0,6 \mathrm{~m}$, sedangkan kecepatan arus tertinggi teridentifikasi pada jam 03.00 dan 15.00 dengan kecepatan berkisar 0,6 $\mathrm{m} / \mathrm{s}$ dan $0,8 \mathrm{~m} / \mathrm{s}$. Pada titik pengamatan di Keunekai pasang tertinggi terjadi pada jam 05.00 dan 17.00 dengan ketinggian permukaan laut 0,6 $\mathrm{m}$, sedangkan kecepatan arus tertinggi terjadi pada jam 03.00 dan 15.00 dengan kecepatan berkisar $0,6 \mathrm{~m} / \mathrm{s}$ dan $0,8 \mathrm{~m} / \mathrm{s}$.

Sedikit berbeda dengan stasiun yang lain, di perairan Ie Meulee teridentifikasi pasang tertinggi terjadi pada jam 17.00 dan 05.00 dengan tinggi permukaan laut berkisar $0,55 \mathrm{~m}$ dan $0,6 \mathrm{~m}$. Kecepatan arus tertinggi terjadi pada jam 17.00 dan 03.00 dengan kecepatan yang berkisar 0,55 $\mathrm{m} / \mathrm{s}$ dan $0,8 \mathrm{~m} / \mathrm{s}$ bertepatan saat proses terjadinya pasang. Pada saat menuju pasang tertinggi, kecepatan arus yang bergerak maksimal tetapi jika diperhatikan pada saat jam 15.00 kecepatan arus juga tinggi sebersar lebih dari $0,5 \mathrm{~m} / \mathrm{s}$ kemudian kecepatannya berkurang. Pasang tertinggi berlangsung tidak terlalu lama, kemungkinan kecepatan arus yang terekam tersebut merupakan kecepatan arus saat perairan sudah bergerak menuju surut.

Secara umum, kecepatan arus tertinggi diperoleh saat menuju pasang karena arus bergerak dengan kecepatan maksimal karena pembangkitan arus oleh angin permukaan. Akan tetapi, pada saat jam 03.00 kecepatan arus cukup lemah. Hal ini disebabkan karena pada saat pasang tertinggi ini terjadi angin darat sehingga arus menuju pasang tertinggi bergesekan dengan angin darat sehingga memperlambat kecepatan arus pada lapisan permukaan (1m) dan menyebabkan lapisan dibawahnya memiliki kecepatan yang hampir lebih cepat dari lapisan permukaan.

Pada saat proses menuju pasang, arus bergerak dengan kecepatan maksimal sedangkan 


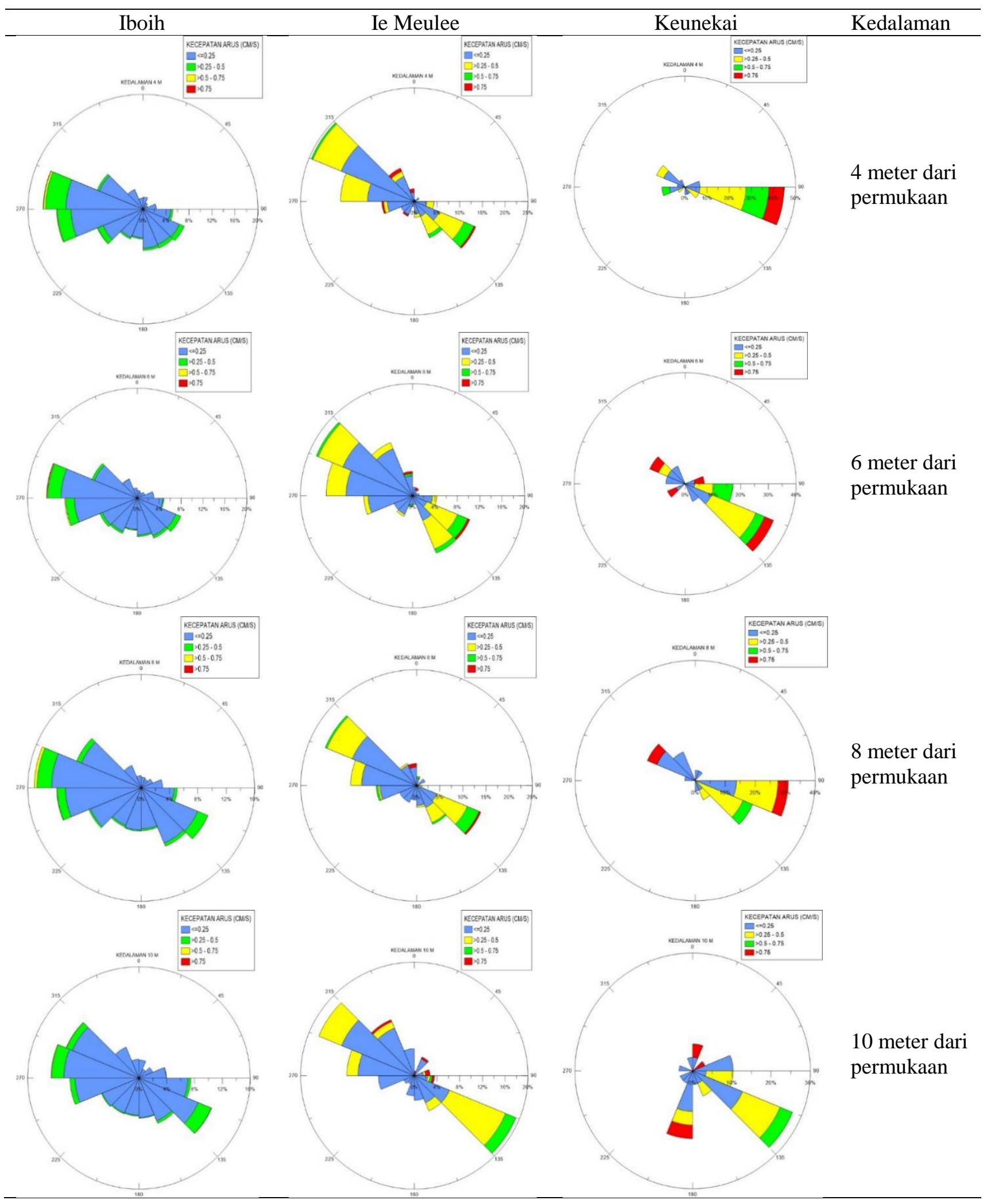

Gambar 4. Grafik mawar arus di perairan Pulau Weh

pada saat pasang tertinggi arus sudah tidak terlalu cepat dan pasang tertinggi tidak berlangsung lama karena arus akan mengalami fase surut kembali dikarenakan terjadinya slack water. Menurut
Aryono et al. (2014), slack water terjadi karena kondisi arus menuju pasang atau menuju surut merupakan kondisi dimana keduanya memiliki kecepatan arus yang kencang akan tetapi ketika 
pasang dan surut mencapai titik tertinggi atau terendah maka kecepatannya menjadi $0 \mathrm{~m} / \mathrm{s}$ kemudian mengalami perubahan arah arus.

Di sisi lain, profil kecepatan arus pada Gambar 5 juga menunjukkan bahwa pasang surut menjadi faktor utama yang memicu mekanisme transpor massa air. Pada kondisi menuju pasang hingga paang tertinggi, perpindahan massa air dikontrol oleh arus pasang surut, namun pada saat menuju surut hingga surut maksimal, terdapat faktor lain yang berpengaruh sehingga pola kecepatan atus lebih fluktuatif dan bersifat asimetris dengan pola pasang surut. Menurut Wisha et al. (2019a) bahwa ketidaksimetrisan
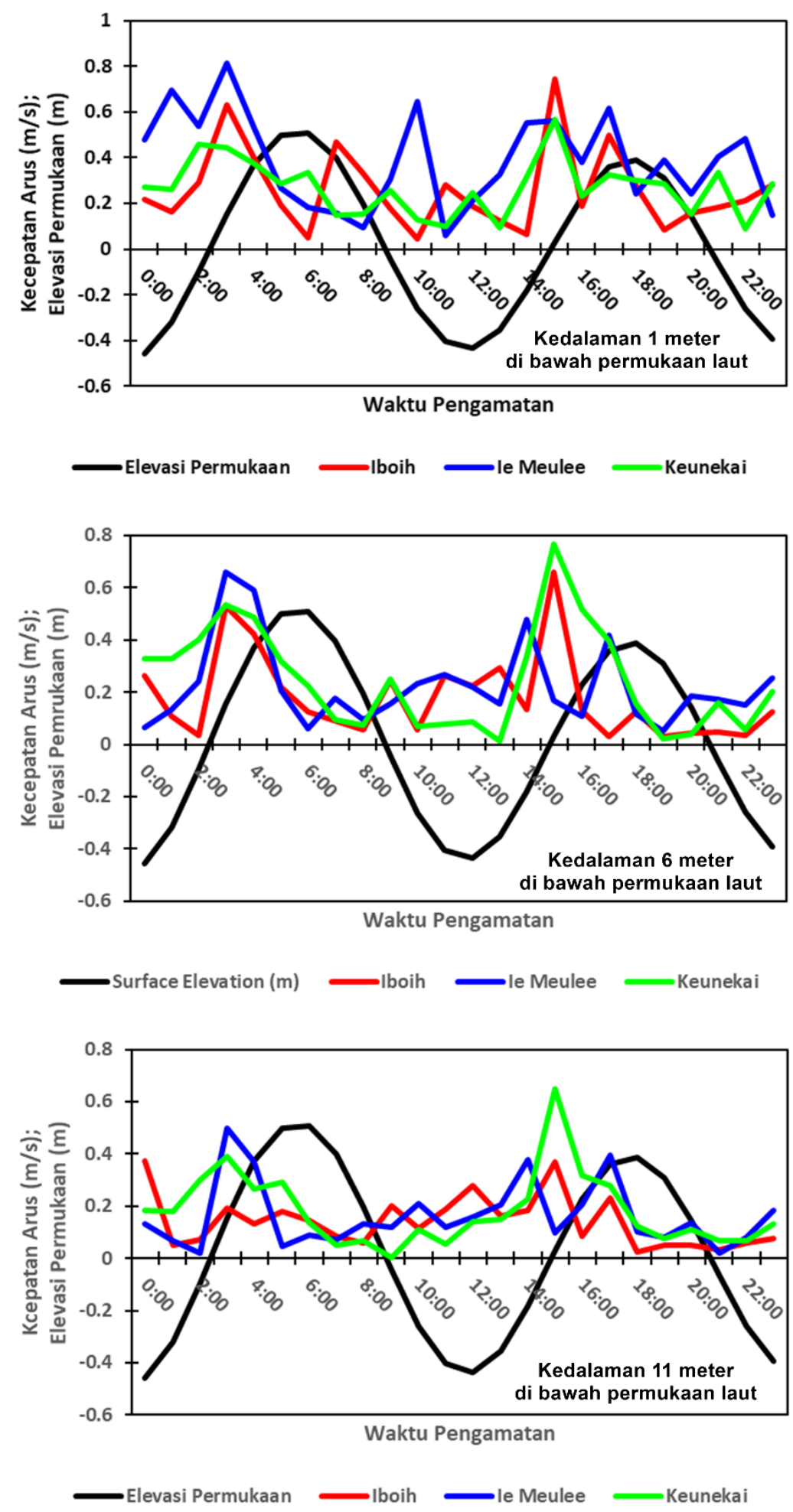

Gambar 5. Grafik profil kecepatan arus 
antara pola pasang surut dan kecepatan arus diakibatkan oleh tekanan oleh faktor fisis lainnya seperti gelombang maupun angin permukaan

\section{Profil suhu di Perairan Pulau Weh}

Secara umum, profil kecepatan arus meningkat saat kondisi menuju pasang dan merurun saat kondisi surut. Pada kedalaman 1 meter di bawah permukaan laut, pengaruh pasang surut tidak terlalu dominan, terlihat pada Gambar 5 bahwa fluktuasi arus baik di Iboih, Ie Meulee, dan Keunekai cenderung lebih acak, hal ini memperlihatkan pengaruh angin permukaan dalam meningkatkan kecepatan arus di permukaan. Pada kedalaman 6 meter di bawah permukaan laut, pengaruh pasang surut sudah mulai terindentifikasi, namun kecepatan arus meningkat sesaat sebelum mencapai pasang maksimal. Pada saat surut maksimum, terhadap ketidaksimetrisan profil kecepatan arus, hal ini diprediksi sebagai pengaruh dari perubahan densitas maupun Spiral Ekman. Dan di kedalaman dekat dasar, pengaruh pasang surut juga masih teridentifikasi dengan semakin melemahnya kecepatan arus akibat dari gaya gesekan dasar dan meningkatnya densitas. Menurut Bayhaqi et al. (2018) distribusi kecepatan arus secara vertikal dipengaruhi oleh beberapa faktor fisis seperti angin, densitas, tegangan dasar, gaya Coriolis dan pasang surut.

Perpindahan massa air yang cukup aktif pada perairan Pulau Weh, berdampak pada sebaran suhu perairan dimana suhu merupakan salah satu faktor fisis yang sangat penting bagi perairan. Fluktuasi suhu perairan di pulau weh berkorelasi positif terhadap perubahan elevasi pasang surut dan fluktuasi arus. Peningkatan kecepatan arus saat menuju pasang juga meningkatkan nilai suhu secara lokal. Di sisi lain, faktor iklim dan interaksi antara atmosfer- samudra juga memiliki peran besar dalam mempengaruhi suhu perairan Pulau Weh.

Pada Perairan Iboih, suhu perairan cenderung rendah di awal pengukuran yakni berkisar antara $26,1-29,8^{\circ} \mathrm{C}$. Fluktuasi suhu di perairan Iboih tergolong stabil dan normal pada Bulan Maret-April 2017 (Gambar 6). Terjadi kenaikan suhu sebesar $\pm 1^{\circ} \mathrm{C}$ pada tanggal 4 April 2017. Kenaikan suhu secara tiba-tiba tersebut lebih besar kemungkinan dipengaruhi oleh faktor eksternal dari darat maupun pengaruh perpiundahan massa air vertikal.

Pada perairan Ie Meulee memiliki nilai suhu yang tinggi terutama pada bulan Maret berkisar $35^{\circ} \mathrm{C}$. Tingginya suhu permukaan laut di perairan Ie Meulee ini disebabkan oleh pengaruh monsun saat musim peralihan I dimana monsun secara dominan akan menggerakkan angin menuju ke selatan dan tenggara (Fadika et al., 2014; Rifai et al., 2020), sehingga pengaruh massa air dari Laut Andaman cukup berpengaruh dalam fluktuasi suhu perairan di Ie Meulee.

Pada perairan Keunekai, suhu cukup tinggi teridentifikasi pada awal pengukuran yang kemudian menurun drastis di akhir Bulan April berkisar antara $25,5-31,8^{\circ} \mathrm{C}$ (Gambar 6). Perairan Keunekai merupakan salah satu perairan yang berbatasan langsung dengan Samudera Hindia, dimana interaksi laut dan atmosfer menjadi faktor utama yang mempengaruhi suhu di kawasan ini. Kombinasi dua osilasi iklim yakni ENSO dan IOD memainkan peran besar dalam perubahan suhu perairan.

Jika diperhatikan lebih mendetail, fluktuasi suhu antara perairan Keunekai dan Iboih terlihat cukup kontras dimana saat suhu di Keunekai tinggi makan suhu perairan Iboih menurun dan sebaliknya seperti fenomena "jungkat jungkit". Hal ini terkait dengan gejala upwelling yang memepnegaruhi suhu di perairan.

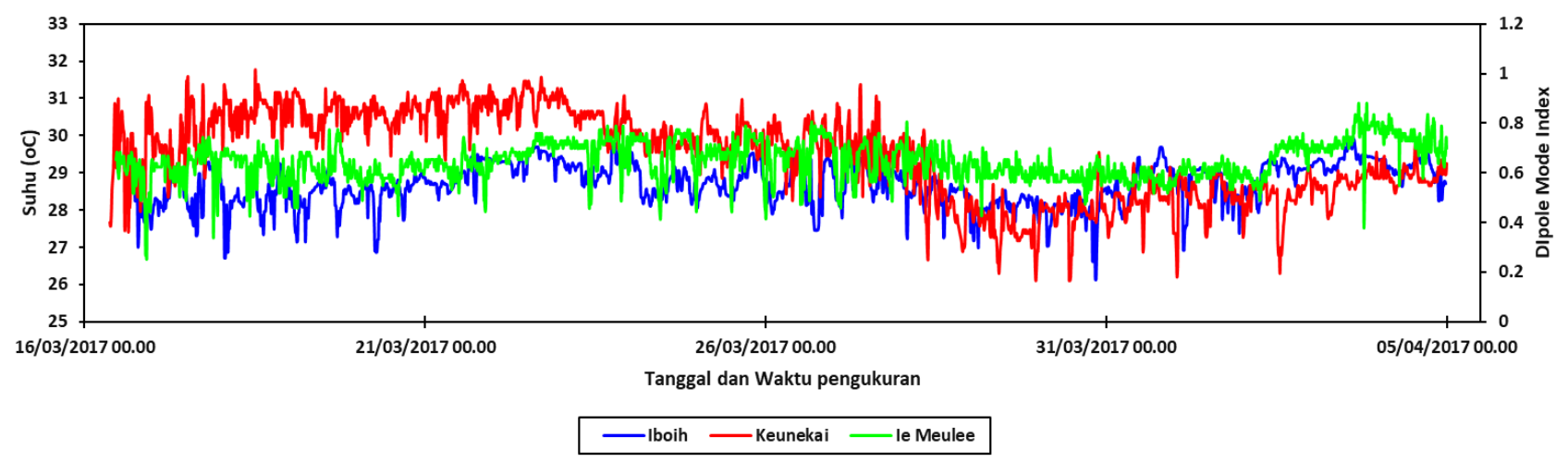

Gambar 6. Fluktuasi suhu pada tiga lokasi pengukuran 
Perindahan massa air menuju ke permukaan akan membawa suhu yang lebih rendah karena adanya kekosongan massa air di permukaan akibat pengaruh angin. Terlihat pada Gambar 6 bahwa pada fase-fase tertentu suhu perairan di Pulau Weh mengalami deklinasi yang cukup signifikan mencapai $26{ }^{\circ} \mathrm{C}$ dan sebaliknya, pada kondisi tertentu, suhu meningkat hingga mencapai $32^{\circ} \mathrm{C}$ yang mengindikasikan fenomena downwelling sehingga suhu di dasar perairan cenederung hangat. "jungkat-jungkit" dari nilai suhu perairan tidak lepas dari pengaruh arus laut dimana secara vertikal dapat memicu transpor massa air, didukung oleh adanya pengaruh Spiral Ekman yang berperan dalam distribusi suhu di perairan secara vertikal.

\section{KESIMPULAN}

Secara vertikal, perpindahan massa air di Perairan Pulau Weh cukup fluktuatif yang mana kecepatan arus tertinngi berada pada kolom perairan dekat permukaan dan semakin lemah saat mendekati dasar. Pada kawasan pesisir dominasi arus pasang surut cukup besar namun pernagruh arus non pasut juga berperan cukup kuat pada mekanisme transpor massa air terutama pada kawasan Iboih dimana mendapatkan pengaruh kuat dariSamudera Hindia dan Teluk Bengala. Dominasi arah perpindahan massa air secara vertikal juga dipengaruhi oleh Spiral Ekman dan gaya Coriolis. Mekanisme perpindahan massa air di pulau weh juga berpengaruh terhadap suhu perairan yang mana fluktuasi suhu mengikuti kondisi pasang surut dan perubahan kecepatan arus laut. Perbedaan perubahan suhu pada bagian utara (Iboih) dan selatan (Keunekai) Pulau Weh disebabkan oleh pengaruh Laut Andaman dan Samudera Hindia yang dibuktikan dengan adanya fenomena jungkat jungkit suhu perairan yang mengindikasikan upwelling saat musim peralihan I di kedua perairan tersebut. Data time series arus laut dan suhu perairan menjadi sangat krusial di Pulau Weh sebagai acuan pengembangan wisata bahari maupun dalam pemantauan kondisi lingkungan perairan.

\section{DAFTAR PUSTAKA}

Al Tanto, T., Husrin, S., Wisha, U.J., Putra, A., \& Putri, R.K., 2016. Karakteristik Oseanografi Fisik (Batimetri, Pasang Surut, Gelombang Signifikan dan Arus Laut) Perairan Teluk Bungus. Jurnal Kelautan: Indonesian Journal of Marine Science and Technology, 9(2):107121. doi: 10.21107/jk.v9i2.1240.

Aryono, M., Purwanto, P., Ismanto, A., \& Rina, R., 2014. Kajian Potensi Energi Arus Laut Di Perairan Selat Antara Pulau Kandang Balak
Dan Pulau Kandang Lunik, Selat Sunda. Journal of Oceanography, 3(2): 230-235.

Azis, M. F., 2006. Gerak air di laut. Oseana, 31(4): 9-21.

Bayhaqi, A., Wisha, U.J., \& Surinati, D. 2018. Modeling Tidal Current of Banten Bay During Transitional Monsoons 2015-2016. Jurnal Segara, 14(2), 95-105. http://dx.doi.org/10.15578/segara.v14i2.6452.

Fadika, U., Rifai, A., \& Rochaddi, B. 2014. Arah dan kecepatan angin musiman serta kaitannya dengan sebaran suhu permukaan laut di selatan pangandaran jawa barat. Journal of Oceanography, 3(3), 429-437.

Gemilang, W.A., \& Wisha, U.J., 2019. Pengaruh Aktifitas Seafloor Fumaroles Terhadap Sebaran Suhu Permukaan dan Kondisi Lingkungan Perairan di Teluk Pria Laot, Pulau Weh. Jurnal Segara, 15(1):31-43. doi: 10.15578/segara.v15i1.6776.

Napitu, R., Surbakti, H., \& Diansyah, G., 2016. Identifikasi Karakteristik Massa Air Perairan Selat Bangka Bagian Selatan. Maspari Journal: Marine Science Research, 8(2):91-100. doi: 10.36706/maspari.v8i2.3485.

Natsir, S.M. \& Wibowo, S.P.A., 2019. Diversitas dan distribusi Foraminifera di Selat Benggala dan sekitarnya, Aceh. Geologi Kelautan, 17(1):1-2. doi: 10.32693/jgk.17.1.2019.560.

Nuriyati, N., Purwanto, P., Setiyono, H., Atmodjo, W., Subardjo, P., Ismanto, A., \& Muslim, M., 2019. Potensi Energi Arus Laut Di Perairan Selat Sunda. Indonesian Journal of Oceanography, 1(1): 45-52.

Ondara, K., Rahmawan, G.A., Wisha, U.J., \& Ridwan, N.N.H., 2017. Hidrodinamika dan Kualitas Perairan untuk Kesesuaian Pembangunan Keramba Jaring Apung (KJA) Offshore di Perairan Keneukai, Nangroe Aceh Darussalam. Jurnal Kelautan Nasional, 12(2): 45-57. doi: 10.15578/jkn.v12i2.6242.

Rifai, A., Rochaddi, B., Fadika, U., Marwoto, J., \& Setiyono, H. 2020. Kajian Pengaruh Angin Musim Terhadap Sebaran Suhu Permukaan Laut (Studi Kasus: Perairan Pangandaran Jawa Barat). Indonesian Journal of Oceanography, 2(1):98-104.

Saputra, V. H., Rifai, A., \& Kunarso, 2017. Variabilitas musiman pola arus di Perairan Surabaya Jawa Timur. Journal of Oseanography, 6(3):439-443.

Silubun, D. T., Gaol, J. L., \& Naulita, Y. (2016). Estimasi Intensitas Upwelling Pantai Dari Satelit Aquamodis Di Perairan Selatan Jawa 
Dan Barat Sumatera. Jurnal Teknologi Perikanan dan Kelautan, 6(1):21-29.

Wardheni, A., Satriadi, A., \& Atmodjo, W., 2014. Studi Arus dan Sebaran Sedimen Dasar di Perairan Pantai Larangan Kabupaten Tegal. Journal of Oceanography, 3(2): 277-283.

Wisha, U.J., Al Tanto, T., Pranowo, W.S., \& Husrin, S., 2018. Current movement in Benoa Bay water, Bali, Indonesia: Pattern of tidal current changes simulated for the condition before, during, and after reclamation. Regional Studies in Marine Science, 18:177-187. doi: 10.1016/j. rsma.2017.10.006.

Wisha, U.J., \& Ilham, I., 2019. Velocity Components of Currents and Transport Mechanism in the Ie Meulee Waters, Weh
Island, Indonesia. Jurnal Kelautan Tropis, 22(2): 93-102. doi: 10.14710/jkt.v22i2.5779.

Wisha, U.J., Dhiauddin, R., \& Gemilang, W.A., 2019a. Tidal Ellipses Analysis Based on Flow Model Hydrodynamic Data Acquisition in Mandeh Bay, West Sumatera. Journal of Geoscience, Engineering, Environment, and Technology, 4(2):93-103. doi: 10.25299/jgeet. 2019.4.2.3115.

Wisha, U.J., Tanto T.A., Ridwan, N.N.H., \& Dhiauddin, R., 2019b. Dampak Fluktuasi Suhu Permukaan Laut Terhadap Kematian Karang di Perairan Pulau Weh, Indonesia. Jurnal Kelautan Nasional, 14(2):103-112. doi: 10.15 578/jkn.v14i2.6979. 